license

\title{
Problematik Data Pemilih pada Pemilihan Kepala Daerah Tahun 2018 Di Kota Medan
}

\author{
Muhammad Husni Thamrin ${ }^{1}$, Muhammad Arifin Nasution ${ }^{2}$, Faiz Albar Nasution ${ }^{3}$ \\ mhusnithamrinnasution@gmail.com,m.arifin.nasution@usu.ac.id, faiznasution92@gmail.com \\ 1 Program Doktor Ilmu Sosial Universitas Diponegoro \\ 2 Program Studi Administrasi Bisnis Universitas Sumatera Utara \\ 3 Program Studi Ilmu Politik Universitas Sumatera Utara
}

DOI https://doi.org/10.22219/sospol.v6i2.11367

Abstract
Updating voter data is one of the most important indicators of the success of the Pilkada in
Indonesia. However, the accuracy of voter data in the city of Medan is still a problem that
affects the level of public participation in the Pilkada. This phenomenon, has an impact on
the constitutional rights of the people, determines the number of polling stations, the
availability of ballots and budget formulation. This study aims to analyze voter data problems
and the role of the Medan KPU in updating voter data. Edwards' theory about policy
implementation is used as an analytical tool for public participation in the 2018 Pilkada in
Medan City. This research uses descriptive qualitative method. Data collection techniques
through documentation and in-depth interviews. Data analysis using Miles and Huberman's
techniques, among others: data reduction, data display and drawing conclusions. The problem
of 2018 Pilkada in Medan was influenced by multi factors, including the accuracy of the DPT,
the HR of Voter Data Updating Officers and regulations which tended to be consistent
regardless of other factors, such as the removal of a very large number of DPT. Therefore, it
requires mutual attention, synergy, and commitment to all related parties to carry out their
duties and functions in Pilkada activities. The urgency of the Pilkada as a means of community
sovereignty must be protected collectively in terms of quantity and quality.

\section{Abstrak}

Pemutakhiran data pemilih menjadi salah satu indikator terpenting dari keberhasilan penyelenggaraan Pilkada di Indonesia. Namun, akurasi data pemilih di kota Medan masih menjadi permasalahan yang mempengaruhi tingkat partisipasi masyarakat pada Pilkada. Fenomena tersebut, berdampak pada hak konstitusional masyarakat, menentukan jumlah TPS, ketersediaan surat suara dan penyusunan anggaran. Penelitian ini bertujuan untuk menganalisis permasalahan data pemilih dan peran KPU Medan dalam melakukan pemutakhiran data pemilih. Teori Edwards tentang implementasi kebijakan dijadikan sebagai alat analisis terhadap partisipasi masyarakat pada Pilkada 2018 di Kota Medan. Penelitian ini menggunakan metode kualitatif deskriptif. Teknik pengumpulan data melalui dokumentasi dan wawancara mendalam. Analisa data menggunakan teknik Miles dan Huberman antara lain: reduksi data, display data dan menarik kesimpulan. Hasil Penelitian menunjukkan problematika data pemilih pada Pilkada 2018 di Kota Medan dipengaruhi multi faktor antara lain akurasi DPT, SDM Petugas Pemutakhiran Data Pemilih dan regulasi yang cenderung konsisten tanpa melihat faktor lainnya, seperti pencoretan DPT dengan jumlah yang sangat

\author{
Keywords \\ Election \\ Participation, \\ Election Policy, \\ Regional Head \\ Election, Voter \\ Data
}

\section{Article History}

Received

February 24,

2020

Revised July 27, 2020

Accepted July

29, 2020

Published

October 13, 2020

\section{Corresponding}

Author

Faiz Albar

Nasution, Program Studi

Ilmu Politik

Universitas

Sumatera Utara,

J1. Dr. A. Sofyan

No.1, Kota

Medan, 20155 besar. Oleh sebab itu, dibutuhkan perhatian, sinergi, dan komitmen bersama kepada seluruh pihak terkait untuk menjalankan tugas dan fungsi pada kegiatan Pilkada. Urgensi Pilkada sebagai sarana kedaulatan masyarakat harus dilindungi kuantitas dan kualitasnya secara kolektif.

\section{Pendahuluan}

Urgensi pemutakhiran data pemilih menjadi salah satu indikator keberhasilan penyelenggaraan Pilkada di Indonesia. Akan tetapi, masalah data pemilih pada Pilkada, hingga saat 
ini masih menjadi persoalan klasik yang tak kunjung tuntas (Nasution, 2020a). Hal ini didasarkan beberapa kasus di daerah masih terjadi tidak efektifnya pemutakhiran data pemilih. Masalah tersebut mengakibatkan partisipasi masyarakat tidak menyentuh pada angka sebenarnya. Oleh karena itu, KPU sebagai penyelenggara diharapkan mampu memberikan pencocokan dan penelitian yang efektif dan akurat (Hayati, 2018).

Merujuk pendapat Ramlan Surbakti, integritas Pemilu dapat dilakukan apabila berdasarkan kepastian hukum yang dirumuskan sesuai asas Pemilu demokratis. Integritas Pemilu dilihat dari kegiatan Pemilu yang jauh dari praktik manipulasi, seperti perhitungan suara, pendaftaran pemilih secara ilegal, intimidasi terhadap pemilih yang bertentangan dengan semangat Undang-Undang Pemilu atau tidak sesuai terhadap prinsip - prinsip demokrasi. Manipulasi pemilihan seperti mencegah warga yang berhak memilih untuk memberikan suara secara bebas atau mencegah warga untuk memilih (Surbakti, 2010). Faktor tersebut, dipengaruhi tidak maksimalnya kinerja Komisi Pemilihan Umum dalam pemutakhiran data pemilih pada kegiatan Pemilu. Sehingga, mengakibatkan hilangnya hak konstitusional masyarakat yang berhak untuk menggunakan hak pilihnya.

Komisi Pemilihan Umum Daerah (KPUD) sebagai garda terdepan Pilkada memiliki kewajiban dalam mensukseskan dan meningkatkan partisipasi pemilih di daerah. Kegiatan tersebut, dapat dirasakan pada Pilkada serentak tahun 2018, diikuti 17 Provinsi, 115 Kabupaten dan 39 Kota, yang salah satunya Kota Medan ikut melaksanakan Pilgub Sumut 2018 (Nasution, 2019). Oleh sebab itu, KPU Sumut menjadikan Peraturan Komisi Pemilihan Umum No. 1 Tahun 2017 sebagai rujukan untuk menerbitkan Keputusan nomor: 86/HK.03.1-kpt/12/Prov/VIII/2017 Tentang Tahapan, Program dan Jadwal Penyelenggaraan Pemilihan Gubernur dan Wakil Gubernur Sumatera Utara Tahun 2018. Regulasi tersebut, menjadi landasan KPU Kota Medan untuk membantu KPU Sumut dalam melaksanakan Pilgub Sumut 2018 di Kota Medan. Sehingga, keberhasilan Penyelenggraan Pilgub sumut 2018 akan dilihat, seberapa efektif KPU Kota Medan melakukan tugas dan fungsinya dalam meningkatkan partisipasi pemilih di Kota Medan.

Selanjutnya, rendahnya partisipasi masyarakat Kota Medan pada Pilkada 2015 yang hanya mencapai 25,38\%, KPU Kota Medan melakukan evaluasi, untuk mengetahui faktor penyebab yang mempengaruhi rendahnya partisipasi pemilih di Kota Medan. Hasil evaluasi menunjukkan salah satu penyebab rendahnya partisipasi pemilih dipengaruhi faktor teknis penyelenggaraan Pemilu seperti: daftar pemilih tetap (DPT) belum mutakhir. Faktor tersebut mengindikasikan, validasi data pemilih sangat menentukan tingkat partisipasi pemilih di Kota Medan. Hemat tersebut, berdasarkan cara menghitung tingkat partisipasi didasarkan dengan jumlah pemilih dan daftar pemilih tetap sebagai bilangan pembaginya. Jika, jumlah DPT tidak tepat maka partisipasi cenderung rendah dan sebaliknya semakin jumlah daftar pemilih tetap tepat, partisipasi menunjukkan kondisi sebenarnya (Damanik, 2018).

Trend partisipasi pemilih di Pilkada Kota Medan dari tahun 2005 sampai 2018 tidak pernah menyentuh angka 60\%. Terlebih lagi, faktor yang mempengaruhi rendahnya tingkat partisipasi pemilih di Pilkada Kota Medan yaitu pemutakhiran data pemilih yang tidak efektif (Suhartono, 2020). Selain itu, Direktur Eksekutif Democracy and Electoral Empowerment Partnership menunjukkan pada Pilkada 2017 yang diikuti oleh 101 daerah dari 7 Provinsi, 18 Kota dan 76 Kabupaten dengan 41,1 juta pemilih, sebesar 691.611 pemilih tidak terdaftar dalam daftar pemilih tetap (Hayati, 2018). Kondisi tersebut, disebabkan adanya daerah yang sulit dijangkau seperti daerah yang memiliki 
banyak pendatang, area perkebunan, dan pulau terpencil (Republika.co.id., 2019). Oleh sebab itu, infrastruktur yang cukup dan anggaran yang besar di Pilkada Kota Medan sudah seharusnya penyelenggara menjaga integritas dalam meningkatkan partisipasi pemilih (Adela, 2017).

Melihat belum mutakhirnya jumlah DPT di Kota Medan, mengharuskan KPU Kota Medan bekerja keras dalam melakukan proses pencocokan dan Penelitian data pemilih yang teknisnya dilaksanakan Petugas Pemutakhiran Data Pemilih (PPDP). Proses Pemutakhiran Data Pemilih sebagai berikut: 1) Penyerahan data penduduk potensial pemilih Pemilu (DP4) oleh Kementerian Dalam Negeri kepada Komisi Pemilihan Umum, 2)Penerimaan DP4, 3) Analisis dan sinkronisasi DP4 dengan DPT Pemilu terakhir, 4) Pengumuman DP4 dan hasil analisis DP4, serta penyampaian oleh KPU Kepada KPU Prov dan Kab/Kota, 5) Pemetaan tempat pemungutan suara oleh Panitia Pemilihan Kecamatan/Panitia Pemungutan Suara, serta penyerahan hasil kepada PPDP, 6) Pencocokan dan penelitian oleh PPDP, 7) Penyusunan dan Penetapan DPS, 8) Pengumuman daftar pemilih sementara dan tanggapan masyarakat untuk perbaikan daftar pemilih sementara/daftar pemilih sementara hasil perbaikan 9) Penyusunan dan penetapan daftar pemilih tetap.

Problem yang sering muncul pada tahapan pemutakhiran data pemilih antara lain; petugas pemutakhiran data pemilih tidak melakukan pencocokan dan penelitian (coklit) secara faktual atau coklit dilakukan oleh oknum lain yang tidak tercantum dalam surat keputusan KPU. Selain itu, petugas pemuktahiran tidak mencoret pemilih yang sudah tidak memenuhi syarat dan tidak mencatat pemilih yang memenuhi syarat untuk terdaftar di DPT. Pelaksanaan Coklit yang dilakukan PPDP merujuk PKPU No. 11 Tahun 2018 tentang Penyusunan Daftar Pemilih Di Dalam Negeri Dalam Penyelenggaraan Pemilihan Umum. Akan tetapi, pada Pilgub Sumut 2018 KPU Kota Medan mencoret 441.170 DPT yang tercantum pada Pilkada 2015. Oleh sebab itu, tulisan ini mencoba melihat seberapa efektif kebijakan yang dilakukan KPU Kota Medan dalam meningkatkan partisipasi Pemilih pada Pilgub Sumut 2018.

Berkaitan dengan Pilkada, sebenarnya telah banyak penulis yang melakukan analisis terhadap masalah pemutakhiran data pemilih pada Pilkada. Akan tetapi, masalah tentang pemutakhiran data pemilih sampai saat ini masih menjadi fenomena yang belum dapat diselesaikan. Hal tersebut juga merupakan salah satu ciri ilmu sosial yang sangat dinamis dan terus berkembang. Oleh sebab itu, beberapa penelitian yang dijadikan rujukan dalam penelitian ini yaitu; studi Indra Muda memperlihatkan Komisi Pemilihan Umum Sumatera Utara dalam pemutakhiran data pemilih sudah dilakukan dengan peraturan perundang - undangan yang berlaku dan dapat menghindari data pemilih ganda pada Pilkada Sumatera Utara Tahun 2008 (Muda, 2011). Hasil penelitian David Susanto mengindikasikan kinerja Panitia pengawas Pemilu tidak maksimal yang berimplikasi terhadap banyaknya masyarakat Kota Medan tidak terdaftar sebagai daftar pemilih tetap (Susanto, 2013).

Selanjutnya, tesis Rachmat Machmud menunjukkan pemutakhiran data pemilih pada Pilkada Kota Kotamobagu Tahun 2015 tidak maksimal, melihat masih ada keluhan masyarakat kepada petugas pemutakhiran data pemilih yang dipengaruhi tanpa adanya supervisi rentang waktu terjadwal (Machmud, 2019). Selain itu, kinerja Komisi Pemilihan Umum Kabupaten Luwu Utara dalam konteks pemutakhiran data pemilih di Pilkada Sulawesi Selatan Tahun 2013 belum efektif, adapun faktor penghambat antara lain data penduduk potensial pemilih pemilu, minimnya partisipasi masyarakat, anggaran dan luas wilayah (Suparto, 2013). Lebih lanjut, Rahmad Nuryadi 
Putra terkait pemutakhiran data Pemilih di Pilkada Kabupaten Bengkalis Tahun 2015 masih terjadi masalah yang disebabkan kelalaian petugas sistem informasi data pemilih (Putra, 2017). Setelah itu, Weriza memperlihatkan Pilkada Kota Padang Panjang Tahun 2015, masih terdapat data pemilih tidak memenuhi syarat pada pemungutan suara (Weriza, 2018). Tambahan lagi, Tota Pasaribu menunjukkan surat keterangan domisili dinilai efektif untuk melindungi hak pilih masyarakat di Pilkada Samosir Tahun 2015 (Pasaribu, 2018).

\section{Implementasi Kebijakan}

Implementasi kebijakan menunjukkan komponen aktivitas kebijakan dalam ranah realitasnya, baik yang dilakukan oleh organisasi pemerintah maupun para pihak yang telah ditentukan dalam kebijakan. Implementasi kebijakan pada dasarnya menjelaskan suatu proses atau langkah yang dilakukan agar sebuah kebijakan dapat mencapai tujuan yang sudah dirumuskan (Sudirman, 2019). Ripley dan Franklin dalam (Winarno, 2012) mengutarakan implementasi ialah kondisi yang terjadi setelah UU diterbitkan yang memberikan otoritas program, kewenangan kebijakan atau hasil empiris. Implementasi kebijakan berupa tindakan perilaku, para pelaksana kebijakan untuk menjalankan program - program yang sudah dirumuskan (Nasution, 2020b). Lebih lanjut, tiga pendekatan yang mempengaruhi berhasilnya implementasi kebijakan, yaitu: 1) tingkat kepatuhan pada ketentuan yang berlaku, 2) adanya kelancarannya pelaksanaan rutinitas kinerja/fungsi dan tidak adanya masalah, 3) Pelaksanaan dan dampak yang dikehendaki terarah. Pendekatan tersebut, digunakan untuk mengukur keberhasilan implementasi kebijakan, sehingga menjadi lebih mudah untuk diidentifikasi.

Selanjutnya, George Edwards menjelaskan empat faktor atau variabel berpengaruh terhadap implementasi kebijakan yaitu: 1) Komunikasi berkaitan dengan transmisi, kejelasan dan konsistensi, 2) Sumber daya berkaitan dengan para pelaksana kebijakan/anggota, serta keahlian yang dimiliki, informasi, wewenang, serta sarana dan prasarana yang dibutuhkan dalam implementasi kebijakan, 3) Disposisi terkait sikap/perilaku para pelaksana kebijakan terhadap integritas implementasi kebijakan, 4) Struktur birokrasi berhubungan dengan tugas dan fungsi, prosedur kerja dan tanggungjawab terhadap implementasi kebijakan (Edwards, 1980). Pendekatan tersebut digunakan untuk menjelaskan sejauh mana implementasi kebijakan pemutakhiran data pemilih pada Pilkada 2018 di Kota Medan, serta potensi dan tantangan yang dihadapi.

Penelitian dalam tulisan ini pada dasarnya mengambil posisi yang berbeda dengan penelitian sebelumnya, dimana penelitian ini menekankan "Problematik Data Pemilih Pada Pemilihan Kepala Daerah Tahun 2018 Di Kota Medan”. Penelitian ini menaruh perhatian pada upaya KPU Kota Medan dalam meningkatkan partisipasi masyarakat pada Pilgub Sumut 2018 dengan cara melakukan validasi data pemilih. Hasil pemutakhiran data pemilih menunjukkan DPT Pilkada 2015 sebesar 1.961.471 menjadi 1.520.301 pada Pilgub Sumut 2018, artinya terdapat 441.170 dihapus dari DPT Pilkada sebelumnya. Masalah tersebut perlu untuk diteliti agar memberikan gambaran bagaimana efektivitas KPU Kota Medan dalam meningkatkan partisipasi pemilih pada Pemilihan Gubernur Sumut Tahun 2018. Penelitian ini bertujuan untuk mengetahui dan menganalisis : (1) Kebijakan KPU Kota Medan dalam pemutakhiran data pemilih pada Pilkada 2018 di Kota Medan, (2) pengaruh pemutakhiran data pemilih terhadap partisipasi pada Pilkada 2018 di Kota Medan. 
Tulisan ini selanjutnya akan dibagi dalam empat bagian. Bagian pertama akan menjelaskan tentang implementasi kebijakan sebagai kerangka teoritis. Bagian kedua memeparkan metode penelitian. Bagian ketiga merupakan hasil dan pembahasan yang berisi tentang Problematika Data Pemilih Pada Pilkada Kota Medan tahun 2018. Bagian keempat adalah kesimpulan

\section{Metode}

Penelitian ini menggunakan pendekatan kualitatif dengan metode deskriptif. Penelitian kualitatif melakukan prosedur penelitian yang menghasilkan data deskriptif berupa kata-kata tertulis maupun lisan dari orang dan perilaku yang diamati (Moleong, 2017). Selanjutnya, metode deskriptif adalah suatu metode dalam meneliti status sekelompok manusia, suatu objek, kondisi, sistem pemikiran, ataupun suatu kelas peristiwa pada masa sekarang. Tujuan dari penelitian deskriptif ini adalah untuk membuat deskripsi, gambaran atau lukisan secara sistematis, faktual dan akurat mengenai fakta - fakta, sifat - sifat serta hubungan antar fenomena yang diselidiki (Nazir, 2014).

Fokus penelitian ini adalah Problematik Data Pemilih Pada Pemilihan Kepala Daerah Tahun 2018. Lokus penelitian terdapat pada Kota Medan dengan 21 Kecamatan. Pengumpulan data didapatkan dari data primer dengan jumlah Informan penelitian sebanyak 7 orang terdiri dari: 1) Komisoner KPU Kota Medan, 2) Ketua Komite Independen Pemantau Pemilu Sumut, 3) Wakil Sekretaris DPC Partai PDIP Kota Medan, 4) Ketua DPC Partai Gerindra Kota Medan, 5) Ketua Karang Taruna Kota Medan, 6) Ketua Hikma (Himpunan Keluarga Besar Mandailing) Kota Medan, 7) Sekretaris Mabmi (Majelis Adat Budaya Melayu Indonesia) Sumut dan data sekunder berupa jurnal, dokumen laporan, koran dll. Selanjutnya, penelitian ini menggunakan teknik analisis data kualitatif model Miles dan Huberman. Aktivitas dalam analisis data kualitatif secara interaktif dan berlangsung secara terus menerus sampai tuntas, sehingga datanya sudah lengkap untuk di analisis. Aktivitas tersebut meliputi : reduksi data, display data, dan penarikan kesimpulan (Miles, Huberman \& Saldana, 2014).

\section{Hasil dan Pembahasan}

\section{Problematika Data Pemilih Pada Pilkada Kota Medan tahun 2018}

Partisipasi masyarakat pada penyelenggaraan Pilkada di Kota Medan dipengaruhi oleh faktor internal dan eksternal. Faktor internal Penyelenggara Pemilu meliputi : DPT belum mutakhir dan Faktor eksternal meliputi Figur calon, peran partai tidak maksimal, kesadaran politik dan kurangnya kepercayaan terhadap pemerintah (Nasution, 2020a). Akan tetapi, permasalahan data pemilih di Kota Medan sudah menjadi penyakit kronis. Faktor tersebut mengakibatkan hilangnya hak konstitusional seseorang, sulitnya menentukan ketersediaan surat suara dan penyusunan rancangan anggaran biaya. Sehingga pentingnya tahapan pemutakhiran data pemilih merupakan faktor yang sangat menentukan tingkat partisipasi masyarakat pada setiap Pilkada di Kota Medan. Berikut trend partisipasi dan daftar pemilih tetap pada setiap Pilkada di Kota Medan pada tabel 1.1.

Melihat partisipasi masyarakat di Pilkada Kota Medan dari Pemilihan Walikota dan Gubernur menggambarkan DPT yang cenderung tidak konsisten dan partisipasi masyarakat dalam menggunakan hak pilihnya masih rendah. Puncak rendahnya tingkat partisipasi masyarakat terjadi pada Pilkada Kota Medan tahun 2015 yang hanya mencapai 25,38\%. Maka dalam meningkatkan partisipasi masyarakat untuk menggunakan hak pilih, KPU Medan melakukan evaluasi untuk 
license

mengetahui faktor penyebab rendahnya partisipasi masyarakat pada Pilkada 2015. Hasil dari evaluasi tersebut menunjukkan faktor yang mempengaruhi rendahnya partisipasi salah satunya yaitu daftar pemilih tetap yang belum mutakhir. Berdasarkan faktor ini KPU Kota Medan melakukan upaya kegiatan Coklit (pencocokan dan penelitian ). Hemat tersebut, dapat dibuktikan dengan pernyataan Bapak E.S sebagai Komisioner KPU Kota Medan (Divisi SDM dan Partisipasi Pemilih) yang mengatakan:

"KPU Kota Medan dalam meningkatkan partisipasi melakukan proses coklit pada tahun 2016, upaya persiapan Pilgub Sumut 2018. Selama Pilkada 2015 kami banyak mendapatkan kritikan seperti DPT ganda dan kami berkordinasi dengan Disdukcapil dalam melakukan coklit selama 1 bulan. Hasilnya kami mencoba mencoret 441.170 jiwa dan itu diperbolehkan dalam PKPU 04 tahun 2015 seperti 11 tugas PPDP, terdapat 8 langkah pencoretan data pemilih yang dikualifikasikan TMS (Tidak Memenuhi Syarat) dengan dibuat berita acaranya. Akhirnya semula DPT Pilkada 2015 sebanyak 1.961.471 pemilih berubah menjadi 1.520.301 pemilih pada Pilgub Sumut 2018”.

Tabel 1.1 Partisipasi Pemilih pada setiap Pilkada di Kota Medan

\begin{tabular}{|c|c|c|c|c|}
\hline No & $\begin{array}{c}\text { Pilkada Kota } \\
\text { Medan }\end{array}$ & $\begin{array}{c}\text { Daftar } \\
\text { Pemilih Tetap }\end{array}$ & $\begin{array}{c}\text { Persentase } \\
\text { Jumlah } \\
\text { Pengguna Hak } \\
\text { Pilih }\end{array}$ & $\begin{array}{c}\text { Persentase Jumlah } \\
\text { tidak } \\
\text { menggunakan } \\
\text { Hak Pilih }\end{array}$ \\
\hline 1 & $\begin{array}{c}\text { Pilkada Wakikota } \\
\text { Medan Tahun 2005 }\end{array}$ & 1.450 .596 & $54,70 \%$ & $45,30 \%$ \\
\hline 2 & $\begin{array}{c}\text { Pilkada Gubernur } \\
\text { Tahun 2008 }\end{array}$ & 1.725 .045 & $47,10 \%$ & $52,90 \%$ \\
\hline 3 & $\begin{array}{c}\text { Pilkada Wakikota } \\
\text { Medan Tahun 2010 }\end{array}$ & 1.961 .837 & $35,68 \%$ & $64,32 \%$ \\
\hline 4 & $\begin{array}{c}\text { Pilkada Wakikota } \\
\text { Medan Tahun 2010 } \\
\text { Putaran II }\end{array}$ & 1.961 .723 & $38,28 \%$ & $61,72 \%$ \\
\hline 5 & $\begin{array}{c}\text { Pilkada Gubernur } \\
\text { Tahun 2013 }\end{array}$ & 2.123 .878 & $36,58 \%$ & $63,42 \%$ \\
\hline 6 & $\begin{array}{c}\text { Pilkada Wakikota } \\
\text { Medan Tahun 2015 }\end{array}$ & 1.998 .835 & $25,38 \%$ & $74,62 \%$ \\
\hline 7 & $\begin{array}{c}\text { Pilkada Gubernur } \\
\text { Tahun 2018 }\end{array}$ & 1.641 .648 & $55,80 \%$ & $44,20 \%$ \\
\hline
\end{tabular}

Sumber: KPUD Kota Medan

Peran KPU Kota Medan dalam meningkatkan partisipasi pemilih pada Pilgub Sumut 2018 di Kota Medan, melalui proses pembenahan data pemilih dinilai tidak efektif. Hemat tersebut, melihat kondisi masyarakat yang sudah dicoret sebagai DPT sebanyak 441.170 jiwa, pada hari pemungutan suara hadir dengan jumlah sebesar 300.000 jiwa. Masalah tersebut, diatasi dengan menggunakan hak pilih setelah pukul 12:00 WIB - 13:00 WIB dan statusnya sebagai pemilih yang tidak terdaftar dalam DPT. Namun, permasalahan yang muncul di lapangan menunjukkan kurangnya ketersediaan surat suara di beberapa TPS yang mengakibatkan banyak masyarakat tidak dapat menggunakan hak pilihnya pada Pilgub Sumut 2018. Hal tersebut dibenarkan oleh E.S sebagai Komisioner KPU Kota Medan (Divisi SDM dan Partisipasi Pemilih),

"Pada hari pemungutan suara, masyarakat yang sudah di coret sebagai TMS, muncul kembali sekitar 300.000 ribu jiwa, tetapi dapat menggunakan hak suaranya dengan E-KTP pada waktu pemilihan jam 12:00 - 13:00. Namun, masalah yang terjadi kekurangan surat suara, tetapi kami sudah ketat dan sudah sesuai mekanisme dalam melakukan coklit. Ketika DPT sudah ditetapkan, jika 14 hari tidak ada 
memberi tanggapan maka bisa dijadikan keputusan untuk ke tahap selanjutnya dan celakanya banyak masyarakat yang berkomentar pada hari pemungutan suara, contoh ekstrem seperti di Kec. Medan Helvetia kami buka TPS di depan rumah warga, namun pemilik rumah terdaftar di TPS yang jauh dan itu murni kesalahan kita. artinya kita tidak mengecek secara faktual sampai ke bawah, jadi banyak kejadian bapak dan anak dapat memilih di TPS yang berbeda”.

Hilangnya hak konstitusional masyarakat Kota Medan dalam menggunakan hak pilih pada Pilgub Sumut 2018 dikarenakan masih banyak terdapat data pemilih ganda dan surat suara habis pada saat pemilihan. Faktor tersebut dipengaruhi tingginya heterogenisasi masyarakat, populasi penduduk dan mutasi kependudukan di Kota Medan tidak sejalan dengan keterlibatan masyarakat untuk mengurus administrasi kependudukannya yang mengakibatkan data penduduk dan data pemilih dalam pilkada memiliki masalah yang cukup kompleks. Hemat serupa merujuk pernyataan dari Lembaga Pemantau pemilu tentang kondisi pada saat Pemilihan Pilgub Sumut 2018 di Kota Medan M.A sebagai Ketua Komite Independen Pemantau Pemilu Sumatera Utara berpendapat,

\footnotetext{
"Khusus Kota Medan masalah yang banyak ditemui yaitu: data ganda, undangan, ketersediaan surat suara habis pada pencoblosan. Seperti di Kec. Medan Denai, Kec. Medan Amplas. Sehingga banyak masyarakat yang protes karena tidak diperbolehkan memilih. Tambahan lagi, di Kecamatan Maimun lebih kepada kesiapan KPU pada Pilgub Sumut 2018 seperti pendataan, undangan C6 yang diberikan ternyata masyarakat tersebut tidak berdomisili di tempat karena banyak masyarakat malas untuk mengurus surat pindah. Faktor - faktor tersebut sangat mempengaruhi rendahnya partisipasi di Kota Medan".
}

Fenomena berlanjut, dengan adanya 117.000 formulir C6 yang dikembalikan kepada KPU Kota Medan dan memunculkan reaksi salah satu anggota DPRD Kota Medan yang menilai PPDP tidak bekerja secara maksimal (Syahputra, 2018). Tidak sampai di situ, berkurangnya jumlah DPT untuk Pilgub Sumut 2018 yang cukup signifikan di Inisiasi oleh Bawaslu Sumatera Utara (Tarigan, 2018). Faktor tidak bekerjanya SDM KPU Kota Medan senada dengan pernyataan B.Z selaku Ketua DPC Gerindra, "Minimnya Kinerja PPD dan KPU di pengarubi SDM, sehingga saya ingin mengajak. teman - teman KPU bersama - sama dan bersinergi untuk mengajak masyarakat berpartisipasi untuk menjaga dan menggunakan hak suaranya".

Kurang optimalnya peran KPU dalam meningkatkan partisipasi pemilih di Kota Medan dipengaruhi keterbatasan SDM penyelenggara Pilgub Sumut 2018 di Kota Medan. Faktor tersebut, dapat dilihat dalam melakukan sosialisasi dan pendataan kepada masyarakat Kota Medan, jika dibandingkan dengan tenaga penyelenggara sekitar 53.000 ribu dari PPK, PPS, KPPS, Panwas dan KPU Kota Medan, apabila dikalkulasikan tidak seimbang. Maka lembaga - lembaga yang bertugas dalam meningkatkan partisipasi masyarakat seperti Partai Politik, Kesbangpol dan lainnya diharapkan mampu bersinergi. Hal tersebut didukung oleh pernyataan Komisioner KPU Kota Medan E.S (Divisi SDM dan Partisipasi Pemilih),

"Melakukan pendataan dari 21 Kecamatan yang memiliki 1,6 juta pemilih, jika dibandingkan dengan tenaga penyelenggara tak lebih dari 3000 ribu orang, mulai dari PPK, PPS dan petugas lainnya sekitar 50.000 yaitu Panwas dan KPU Kota Medan, untuk melakukan tahapan - tahapan sosialisasi, pendataan, pancalonan sampai hari pemilihan, tidak sebanding dengan populasi pemilih. Apalagi dana penyelenggara dari APBD yang dialokasikan tidak banyak, karena kita membentuk relawan demokrasi, maka kalau di kalkulasikan tidak seimbang dan tidak bisa dihindarkan masalah - masalah pendataan, C6 undangan tidak terbagi dan lain - lain". 
Problematika data pemilih di Kota Medan, mendapatkan stereotipe negatif dari beberapa organisasi adat dan sosial. Sterotipe tersebut, berupa kritikan yang menjurus kepada KPU Kota Medan sebagai mesin utama penyelenggara Pilkada. Oleh sebab itu, euforia Pilkada di Kota medan menunjukkan proses dan hasil tidak sejalan dengan jumlah pemilih yang menggunakan hak pilih. Bahkan, pesta demokrasi di Pilgub Sumut 2018 ternyata tidak mengedepankan hak konstitusional masyarakat Kota Medan. Sehingga, kegiatan dari Pilgub Sumut 2018 di Kota Medan tidak sebanding dengan biaya yang dikeluarkan sampai miliaran rupiah.

Peran KPU Kota Medan dalam pembenahan data pemilih untuk meningkatkan partisipasi masyarakat pada Pilgub Sumut 2018 di Kota Medan tidak sepenuhnya gagal. Melihat partisipasi pemilih pada Pilkada Medan 2015 hanya 25,38\% naik signifikan menjadi 55,80\% pada Pilgub Sumut 2018. Akan tetapi, tidak tercapainya target KPU Kota Medan sebesar 78\% dan kondisi empiris dari beberapa penelitian terdahulu mengenai meningkatkan partisipasi pada Pilgub Sumut 2018 dipengaruhi isu politik identitas (Nasution, 2019), (I. Pasaribu, 2018), (Simamora, 2018). Pernyataan para informan mengindikasikan bahwa partisipasi masyarakat Kota Medan di Pilkada, memungkinkan untuk dapat ditingkatkan kembali. Hemat tersebut, berdasarkan grafik trend partisipasi pemilih di Pilkada Kota Medan yang setiap periodenya mengalami peningkatan.

Penelitian ini mencoba memberikan rekomendasi kepada KPU untuk menghadapi Pilkada 2020 di Kota Medan. Selanjutnya, penelitian ini merujuk pendapat George Edwards tentang upaya mencapai keberhasilan implementasi kebijakan yang dipengaruhi oleh empat faktor, yakni; 1) Komunikasi, 2) Sumber daya, 3) Disposisi, 4) Struktur Birokrasi, di mana keempat faktor tersebut akan saling berhubungan antara satu dengan lainnya (Edwards, 1980).

Pertama, implementasi kebijakan akan terpenuhi, apabila komponen - komponen dan tujuan kebijakan dipahami oleh pelaksana kebijakan. Lebih lanjut, tujuan kebijakan akan kongkrit jika dikomunikasikan secara tepat dengan para pelaksana kebijakan. Konsistensi atau keseragaman dari ukuran komponen dan tujuan, perlu disosialisasikan agar Petugas Pemutakhiran Data Pemilih mengetahui secara tepat terhadap kegiatan pemutakhiran data pemilih. Kendati demikian, suatu regulasi penyelenggara Pilkada, harus diberikan sosialisasi dan pemberdayaan yang efektif kepada Petugas Pemutakhiran Data Pemilih. Oleh sebab itu, perencanaan dan kesiapan KPU Kota Medan dalam pencocokan dan penelitian, akan terpenuhi dalam membenahi data pemilih di Kota Medan.

Kedua, apabila muatan/materi kebijakan sudah disosialisasikan secara jelas dan konsisten, sering kali pelaksana kebijakan kekurangan Sumber daya untuk melaksanakan kebijakan agar berjalan efektif. Komponen tersebut, berupa sumberdaya manusia dan sumber daya finansial. Sumber daya menjadi mesin penggerak dan indikator terpenting dalam implementasi kebijakan. Oleh sebab itu, SDM yang meliputi KPU dan jajaran, terkhususnya Petugas Pemutakhiran Data Pemilih harus terus diberikan pembinaan agar melakukan pendataan pemilih secara mekanisme dan faktual. Bahkan, KPU harus mampu mengukur ketepatan, kebutuhan finansial dalam penyelenggara Pilkada, agar tidak menjadi alasan jika dievaluasi oleh Bawaslu dan pemerhati Pemilu.

Ketiga, disposisi merupakan perilaku yang dimiliki para pelaksana kebijakan, seperti komitmen, kejujuran, dan demokratis. Integritas pelaksana kebijakan sangat mempengaruhi implementasi kebijakan, apabila kebijakan tidak diimplementasikan sesuai dengan aturan, maka berimplikasi terhadap hasil yang tidak diharapkan. Oleh karena itu, KPU harus memiliki integritas, 
agar terwujudnya kedaulatan hak konstitusi masyarakat Kota Medan. Hemat penulis, berdasarkan data yang menunjukkan banyaknya masyarakat Kota Medan tidak dapat menggunakan hak pilih dipengaruhi masalah teknis. Dengan demikian, penyelenggara Pilkada harus mempertimbangkan faktor - faktor lain dalam upaya mengembalikan kepercayaan masyarakat Kota Medan untuk menggunakan hak pilihnya.

Keempat, struktur organisasi yang bertugas menjalankan kebijakan memiliki pengaruh yang signifikan terhadap implementasi kebijakan. Mengutip Gabriel Almond tentang struktur fungsional menjelaskan struktur lembaga akan mempengaruhi fungsinya dalam membuat kebijakan (Mas'oed, 2011). Dengan demikian, para pemangku jabatan pada penyelenggara Pemilu diharapkan berfungsi dan berkontribusi menjalankan tugas, agar diikuti Petugas Pemutakhiran Data Pemilih dalam melakukan pembenahan data pemilih di Kota Medan. Setelah itu, kepemimpinan individu di KPU nantinya mentransformasikan nilai - nilai untuk mewujudkan budaya kerja terhadap petugas pemutakhiran data pemilih di Kota Medan. Sehingga, prosedur standar operasional yang dapat menghambat kegiatan coklit dapat dihindarkan dan memberi cara - cara efektif terhadap pemutakhiran data pemilih.

\section{Kesimpulan}

Hasil Penelitian menunjukkan problematika data pemilih pada Pilgub Sumut 2018 dipengaruhi multi faktor diantaranya adalah akurasi DPT, SDM Petugas Pemutakhiran Data Pemilih dan regulasi yang cenderung konsisten tanpa melihat faktor lainnya, seperti pencoretan 441.170 DPT. Oleh sebab itu, dalam memperbaiki masalah tersebut, dibutuhkan perhatian, sinergi, dan komitmen bersama kepada seluruh pihak terkait untuk menjalankan tugas dan fungsi pada kegiatan Pilkada. Urgensi Pilkada sebagai sarana kedaulatan masyarakat harus dilindungi kuantitas dan kualitasnya secara kolektif. Dengan demikian, penyelenggara Pilkada melakukan pembenahan data pemilih diharapkan mampu mencocokkan secara faktual sampai ke bawah agar tidak adanya hak konstitusional masyarakat yang hilang. Sehingga, pada Pilkada 2020 mendatang tidak hanya sekedar meningkatkan partisipasi pemilih, akan tetapi masyarakat teredukasi dan cerdas mengambil peran dalam seluruh tahapan proses Pilkada.

\section{Referensi}

Adela, F. P., \& Truna, D. S. (2017). Partisipasi Rakyat Dalam Pengawasan Pilkada, Antisipasi Tingginya Angka Golput Di Pilkada Sumut 2018. Jumal Bawaslu, 3(1), 107-118. Retrieved from http:/ /jurnal.bawaslu.go.id/Edisi-I.pdf\#page=112

Damanik, R. A. (2018). Dinamika Validasi Data Pemilih Dan Partisipasi Pemilih Di Kota Medan. Retrieved from https://kpud-medankota.go.id/dinamika-validasi-data-pemilih-danpartisipasi-pemilih-di-kota-medan/

Edwards, G. C. (1980). Implementing Public Policy. Washington, D.C: Congressional Quarterly Press. Hayati, N. N. (2018). Pendataan Pemilih Pilkada dan Segala Permasalahannya. Kompas.Com, p. 1. Retrieved from https://nasional.kompas.com/read/2018/01/30/17432821/pendataanpemilih-pilkada-dan-segala-permasalahannya?page $=1$

Machmud, R. (2019). Efektivitas Panitia Pemutakhiran Data Pemilih (PPDP) Pada Pemilihan Gubernur dan Wakil Gubernur Di Kota Kotamobagu Tahun 2015. HOLISTIK, Journal Of Social and Culture, 12(3), 127-146. Retrieved from 
https://ejournal.unsrat.ac.id/index.php/holistik/article/view/25771/25416

Mas'oed, M. (2011). Perbandingan Sistem Poltiik. Yogyakarta: Gadjah Mada University Press.

Miles, M. B., Huberman, M. \& Saldana. (2014). Qualitative Data Analysis: A Methods Sourcebook. (H. Salmon, Ed.) (3rd ed.). London: SAGE.

Moleong, L. J. (2017). Metodologi Penelitian Kualitatif (27th ed.). Bandung: Remaja Rosdakarya.

Muda, I. (2011). Cara Pemutakhiran Data Daftar Pemilih Tetap Pemilu Kepala Daerah/Wakil Kepala Daerah Berdasarkan Peraturan KPU Nomor 09/2010. Jurnal Perspektif, 4(1), 1-8. Retrieved from https://www.ojs.uma.ac.id/index.php/perspektif/article/view/76

Nasution, F. A., \& Kushandajani, K. (2019). Partisipasi Politik Masyarakat Kecamatan Medan Maimun Pada Pemilihan Gubernur Sumatera Utara Tahun 2018. JPPUMA Jurnal Ilmu Pemerintahan dan Sosial Politik Universitas Medan Area, 7(2), 227-235. https://doi.org/10.31289/jppuma.v7i2.3015

Nasution, F. A. (2020a). Menakar Partisipasi Politik Masyarakat Kota Medan Terhadap Pemilihan Walikota Medan Tahun 2020: Indonesia. Politeia: Jurnal Ilmu Politik, 12(2), 97-113. Retrieved from https://talenta.usu.ac.id/politeia/article/view/3955

Nasution, F. A., \& Taher, Z. (2020b). Pemberdayaan Pemerintahan Desa Dalam Membuat Peraturan Desa di Desa Bandar Khalipah Kabupaten Deli Serdang. Jurnal Ilmiah Muqoddimab: Jurnal Ilmu Sosial, Politik dan Humaniora, 4(2), 53-60. https://doi.org/10.31604/jim.v4i2.2020\%25p

Nazir, M. (2014). Metode Penelitian. Bogor: Ghalia Indonesia.

Pasaribu, I. (2018). Bekerjanya Politisasi Identitas Pada Pilkada Sumut 2018 (Menakar Pengaruh Isu Agama Terhadap Kemenangan Edy Rahmayadi dan Musa Rajekshah). Jurnal Adhyasta Pemilu, 4(1), 11-28. Retrieved from https://ppid.bawaslu.go.id/sites/default/files/informasi_publik/4. Jurnal Adhyasta Pemilu 02.pdf\#page $=15$

Pasaribu, T. R. (2018). Penerapan Pemilu Berintegritas dan Jaminan Kesetaraan Hak Politik Dalam Pendaftaran Pemilih: Studi Kasus Pada Pilkada Samosir Tahun 2015. Jurnal Wacana Politik, $\quad 3(2), \quad$ 121-128. Retrieved from http://jurnal.unpad.ac.id/wacanapolitik/article/view/17086

Putra, R. N. (2017). Pemutakhiran Data Pemilih Pada Pemilihan Bupati dan Wakil Bupati Kabupaten Bengkalis di Kecamatan Mandau dan Kecamatan Bantan Tahun 2015. JOM FISIP, $\quad 4(2), \quad 1-12 . \quad$ Retrieved from https://www.neliti.com/publications/183214/pemutakhiran-data-pemilih-padapemilihan-bupati-dan-wakil-bupati-kabupaten-bengk

Republika.co.id. (2019). KPU Jelaskan Kendala Pemutakhiran Data Pemilih Pemilu 2019. Republika.Co.Id, p. $1 . \quad$ Retrieved from https://nasional.republika.co.id/berita/q4i13k428/kpu-jelaskan-kendala-pemutakhirandata-pemilih-pemilu-2019

Simamora, S. D. V. (2018). Isu Identitas Etnis dan Agama Dalam Kontes Politik (Kasus Pemilihan Gubernur Sumatera Utara 2018). Interaksi Online, 7(4), 1-13. Retrieved from https://ejournal3.undip.ac.id/index.php/interaksi-online/article/view/24932/22226

Sudirman, F. A. (2019). Tinjauan Implementasi Pembangunan Berkelanjutan: Pengelolaan Sampah Kota Kendari. Sospol: Jurnal Sosial Politik, 5(2), 291-305. Retrieved from 
http://ejournal.umm.ac.id/index.php/sospol/article/view/9821/pdf

Suhartono, E. (2020). Menakar Kadar Partisipasi Pemilih di Kota Medan Menyongsong Pilkada Serentak 2020. Retrieved from https://kpud-medankota.go.id/menakar-kadarpartisipasi-pemilih-di-kota-medan-menyongsong-pilkada-serentak-2020/

Suparto, D. (2013). Kinerja KPU Kab Luwu Utara Dalam Pemutakhiran Data Pemilih Pada PIlgub Sulawesi Selatan Tahun 2013. Otoritas, 3(2), 163-176. Retrieved from https://jurnal.unismuh.ac.id/index.php/Otoritas/article/view/75

Surbakti, R. (2010). Memahami Ilmu Politik. (F. A. Herfan Djoni, Ed.) (VII). Jakarta: PT Grasindo.

Susanto, D. (2013). Implementasi Pengawasan Tahapan Pemutakhiran Data Pemilih (DPT) Dalam Pemilu Kepala Daerah Kota Medan Tahun 2010 (Studi Kasus Kelurahan Pusat Pasar Kecamatan Medan Kota, Kota Medan). Jumal Perspektif, 6(1), 30-45. Retrieved from https://www.ojs.uma.ac.id/index.php/perspektif/article/view/119

Syahputra, A. (2018). 200.000 C6 Pilgubsu Kembali ke KPU, Komisi A: PPDP Tidak Bekerja. Medanbisnisdaily.Com, $\quad$ p. $1 . \quad$ Retrieved from http://www.medanbisnisdaily.com/news/online/read/2018/08/27/49074/200_000_c 6_pilgubsu_kembali_ke_kpu_komisi_a_ppdp_tidak_bekerja/

Tarigan, S. (2018, April). Bawaslu Panggil Petugas 33 Kabupaten/Kota, Bahas Hilangnya 1 Juta Pemilih Pilgub Sumut. Tribun-Medan. Com, p. 1. Retrieved from https://medan.tribunnews.com/2018/04/04/bawaslu-panggil-petugas-33kabupatenkota-bahas-hilangnya-1-juta-pemilih-pilgub-sumut

Weriza, dkk. (2018). Budaya Kerja Petugas Pemutakhiran Data Pemilih Dalam Pemilukada Di Kota Padang Panjang. Jurnal Antropologi: Isu-Isu Sosial Budaya, 20(2), 213-222. Retrieved from http://jurnalantropologi.fisip.unand.ac.id/index.php/jantro/article/view/110

Winarno, B. (2012). Kebijakan Publik, Teori, Proses, dan Studi Kasus Edisi \& Revisi Terbaru. Yogyakarta: CAPS.

\section{Wawancara}

B.Z. (2019). Kantor DPC Gerindra Kota Medan, 24 Juni 2019

E.S. (2019). Kantor KPU Kota Medan, 19 Juni 2019.

M.A. (2019). Jl. Dr, Mansur Kota Medan, 15 Juni 2019

S.A.L. (2019). Kantor Hikma Kota Medan, 3 Juli 2019

S. (2019). Kantor Karang Taruna Kota Medan, 15 Juli 2019

T. (2019). Fakultas Ilmu Budaya USU Kota Medan. 5 Juli 2019 